\title{
INTEGRASI METODE NEIVE BAYES DAN SOFTWARE RAPIDMINER DALAM ANALISIS HASIL USAHA PERUSAHAAN DAGANG
}

\author{
Rika Nofitri, Novica Irawati \\ Sekolah Tinggi Manajemen Infromatika dan Komputer Royal \\ email: nofitririka15@gmail.com
}

\begin{abstract}
Profits are the main target in a company. Every company wants the benefits achieved in accordance with the desired target. However, the company thinks the target achieved is due to the large sales. The company does not see other factors that affect profit outcomes such as costs, stocks, purchases and other factors in preparing the company's final report. In addition, the data management that has been carried out so far is not comprehensive, because a lot of data must be analyzed so that it requires tools to manage it. This study intends to analyze the factors that influence profit outcomes based on the profit data. By integrating using the Naive Bayes method and rapidminer software tools, this technique will produce information in the form of a pattern of relationships or interrelationships between factors with each other in influencing the achievement of profits. While rapidminer software to simplify the analysis of data on profit. The results of this study are expected to be the basis for predicting the profits of trading companies,
\end{abstract}

Keywords: Profit Results, Data Mining, Neive Bayes, Rapidminer

\begin{abstract}
Abstrak: Keuntungan menjadi target utama di sebuah perusahaan. Setiap perusahaan menginginkan keuntungan yang dicapai sesuai dengan target yang diinginkan. Akan tetapi perusahaan beranggapan target yang dicapai tersebut didapat karena hasil penjualan yang besar. Perusahaan tidak melihat faktor lainnya yang mempengaruhi hasil keuntungan seperti biaya, stok, pembelian dan faktor-faktor lain dalam menyusun laporan akhir perusahaan. Selain itu, pengelolaan data yang dilakukan selama ini pun tidak menyeluruh, dikarenakan banyak nya data yang harus dianalisis sehingga memerlukan alat bantu dalam pengelolaannya. Penelitian ini bermaksud untuk menganalisa faktor yang mempengaruhi hasil keuntungan berdasarkan data hasil keuntungan. Dengan melakukan integrasi menggunakan metode naive bayes dan alat bantu software rapidminer, teknik ini akan menghasilkan informasi berupa pola hubungan atau keterkaitan antar factor satu dengan lainnya dalam mempengaruhi tercapainya laba. Sedangkan software rapidminer untuk mempermudah dalam menganalisis data hasil keuntungan.Hasil dari penelitian ini diharapkan menjadi landasan untuk memprediksi hasil keuntungan perusahaan dagang,
\end{abstract}

Kata Kunci : Hasil Keuntungan, Data Mining, Neive Bayes, Rapidminer

\section{PENDAHULUAN}

Keuntungan menjadi target utama di sebuah perusahaan. Setiap perusahaan menginginkan keuntungan yang dicapai sesuai dengan target yang diinginkan. Selama ini perusahaan beranggapan target yang dicapai tersebut didapat karena hasil penjualan yang besar. Perusahaan tidak melihat 
DOI: https://doi.org/10.33330/jurteksi.v6i1.393

Available online at http://jurnal.stmikroyal.ac.id/index.php/jurteksi

faktor lainnya yang mempengaruhi hasil keuntungan seperti biaya, stok, pembelian dan faktor-faktor lain dalam menyusun laporan akhir perusahaan.

Sama halnya dengan perusahaan UD. Arif Jaya yang bergerak pada penjualan makanan ringan, pengusaha hanya terfokus pada factor omset dalam melihat kinerja usahanya. Hal ini jelas mengabaikan factor lain sehingga proses evaluasi dilakukan dengan factor yang tidak utuh. Ketidak utuhan evaluasi ini akan berdampak pada berkurangnya laba yang mestinya dicapai bahkan sampai pada kerugian dan kebangkrutan. Gudang data yang telah disusun bertahun-tahun belum mampu digunakan untuk membantu usaha dalam menemukan informasi yang berharga untuk kemajuan perusahaan.

Berdasarkan permasalahan yang telah dikemukakan, peneliti berkeingainan melakukan kajian terhadap gudang data keuangan perusahaan untuk menemukan barang berharga yang disebut dengan informasi Proses penggalian informasi menggunakan teknik data mining menggunakan metode neive bayes yang diintegrasikan menggunakan software Rapidminer. Teknik ini akan menghasilkan informasi berupa pola hubungan atau keterkaitan antar factor satu dengan lainnya dalam mempengaruhi tercapainya laba. Sedangkan software rapidminer untuk mempermudah dalam menganalisis data hasil keuntungan.

Teknik data mining dengan metode neive bayes merupakan algoritma yang menerapkan teori Bayes dalam klasifikasi [1]. Teorema keputusan Bayes adalah adalah pendekatan statistik yang fundamental dalam pengenalan pola (pattern recoginition).

\section{Hasil Keuntungan}

Keuntungan adalah diperolehnya kelebihan atas penghasilan selama satu periode akuntansi setelah melakukan perhitungan biaya [2]. Pengertian laba yang diamati oleh struktur akuntansi sekarang ini adalah selisih pengukuran pendapatan dan biaya. Informasi yang didapat dari laporan akuntansi terkait laba ini akan memberikan informasi tentang kinerja perusahaan yag dibutuhkan untuk mengelola perusahaan dimasa depan [3].

\section{Definisi Data Mining}

Data mining atau penambangan data dapat didefinisikan sebagai proses seleksi, eksplorasi, dan pemodelan dari sejumlah besar data untuk menemukan pola atau kecenderungan yang biasanya tidak disadari keberadaannya [4].

Data mining merupakan sebuah analisa dari observasi data dalam jumlah besar untuk menemukan hubungan yang tidak diketahui sebelumnya dan dua metode baru untuk meringkas data agar mudah dipahami serta kegunaannya untuk pemilih data Sebenarnya data mining adalah sebagian dari proses Knowledge Discovery in Database. Melalui beragam algoritma dan teknik, data mining bertujaun untuk mengekstrak pengetahuan dari kumpulan data yang alam tersimpan [5].

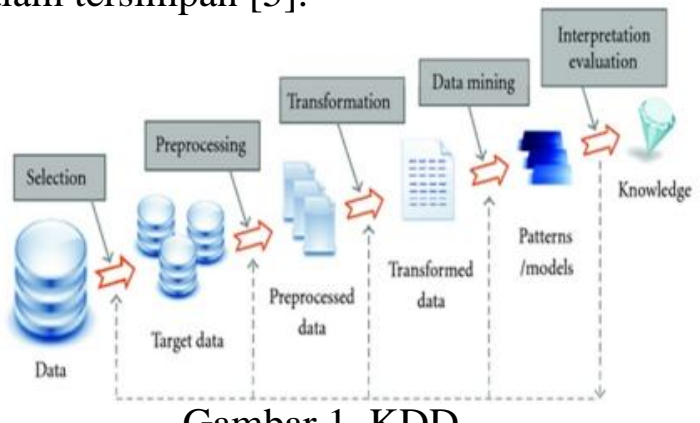

Gambar 1. KDD 
DOI: https://doi.org/10.33330/jurteksi.v6i1.393

Available online at http://jurnal.stmikroyal.ac.id/index.php/jurteksi

Gambar 1 menunjukkan bahwa data mining merupakan bagian dari KDD yang memiliki langkah sebagai berikut :

1. 1.Selection : Data dipilih dari kumpulannya sesaui dengan kebutuhan yang akan diteliti.

2. Data Preprocessing : Dimulai dari proses data cleaning(pembersihan data) dari kesalahan, noise, data ganda, tidak konsisten, hilang, rusak. Selanjutnya dilakukan proses enrichment, guna melengkapi data yang ada dengan informasi lain yang dibutuhkan dari eksternal data yang ada.

3. Data Transformation : Melakukan perubahan bentuk menjadai symbol atau coding pada data yang sebelumnya sudah mengalami preprocessing. Hal ini bertujuan untuk mempermudah proses ekstaraksi pengetahuan karena data yang akan diproses sudah disesuaikan dengan konsep data mining.

4. Data mining : Mengimplementasikan algoritma dan tenik mining untuk mengekstrak pengetahuan baik berupa penemuan pola, kecendrungan, prediksi dalan lainnya.

5. Evaluation : Menguji kesesuaikan dari hasil pengetahuan yang telah diekstrak dengan fakta yang sebenarnya. Proses ini juga dilakukan untuk menyajikan infromasi yang dapat dipahami oleh pihak pengambil keputusan

\section{Metode Naive Bayes}

Naive Bayes merupakan sebuah pengklasifikasian probabilistik sederhana yang menghitung sekumpulan probabilitas dengan menjumlahkan frekuensi dan kombinasi nilai dari dataset yang diberikan [6].

Naive Bayes didasarkan pada asumsi penyederhanaan bahwa nilai atribut secara kondisional saling bebas jika diberikan nilai output. Dengan kata lain, diberikan nilai output, probabilitas mengamati secara bersama adalah produk dari probabilitas individu [1]

$$
P(H \mid X)=\frac{P(X \mid H) P(H)}{P(X)}
$$

$\mathrm{P}(\mathrm{H} \mid \mathrm{X})$ : peluang dari hipotesa $\mathrm{H}$ berdasar dari kondisi $\mathrm{X}$

$\mathrm{X} \quad$ :Sampel data dari kelas (label) yang tidak diketahui

$\mathrm{H}$ :merupakan hipotesa bahwa X adalah data dengan klas (label) C.

$\mathrm{P}(\mathrm{H})$ : peluang dari hipotesa $\mathrm{H}$

$\mathrm{P}(\mathrm{X})$ :adalah peluang dari $\mathrm{X}$ yang diamati

$\mathrm{P}(\mathrm{X} \mid \mathrm{H})$ : peluang $\mathrm{X}$, berdasarkan kondisi pada hipotesa $\mathrm{H}$ Jika asumsi atribut tidak saling terkait (conditionally independent), maka:

$$
P\left(X \mid C_{i}\right)=\prod_{k=1}^{n} P\left(x_{k} \mid C_{i}\right)
$$

Bila $\mathrm{P}(\mathrm{X} \mid \mathrm{Ci})$ dapat diketahui melalui perhitungan di atas, maka klas (label) dari data sampel $\mathrm{X}$ adalah klas (label) yang memiliki $\mathrm{P}(\mathrm{X} \mid \mathrm{Ci}) * \mathrm{P}(\mathrm{Ci})$ maksimum.

Untuk klasifikasi dengan data kontinyu digunakan rumus Densitas Gauss sebagai beikut.

$$
P\left(X_{i}=x_{i} \mid Y=y_{j}\right)=\frac{1}{\sqrt{2 \pi \sigma_{i j}}} e^{-\frac{\left(x_{i}-\mu_{i j}\right)^{2}}{2 \sigma^{2} i j}}
$$

Di mana :

P : Peluang

Xi : Atribut ke i

xi : Nilai atribut ke i 
DOI: https://doi.org/10.33330/jurteksi.v6i1.393

Available online at http://jurnal.stmikroyal.ac.id/index.php/jurteksi

Y : Kelas yang dicari

yi : Sub kelas Y yang dicari

: mean, menyatakan rata - rata dari seluruh atribut

$\sigma$ :Deviasi standar, menyatakan varian dari seluruh atribut.

Akurasi $=\frac{\text { Jml Prediksi Yang Benar }}{\text { Jml Prediksi keseluruhan }}$

Error $=\quad$ Jml Prediksi Yang Salah

Jml Prediksi keseluruhan

\section{Software RapidMiner}

RapidMiner adalah aplikasi data mining berbasis open-source yang terkemuka dan ternama. Didalamnya terdapat aplikasi yang berdiri sendiri untuk analisis data dan sebagai mesin data mining seperti untuk loading data, transformasi data, pemodelan data, dan metode visualisasi data [7]. RapidMiner pertama kali dinamai Yet Another Learning Environment atau singkat YALE. Pada tahun 2007 akhirnya diganti namanya menjadi RapidMiner.

\section{METODE}

Adapun kerangka kerja dari penelitian ini yaitu sebagai berikut :

1. Identifikasi Masalah

Masalah yang diidentifikasi dalam penelitian ini adalah belum digunakannya gudang data keuangan perusahaan untuk mendapatkan informasi yang berguna bagi perusahaan.

2. Mengkaji Bahan Literatur

Ini bertujuan untuk mendapatkan pemahaman yang dalam terhadap maslah yang akan diteliti dan metode yang digunakan sebagai solusi. Bahan literatur yang sangat penting publikasi karya ilmiah baik jurnal maupun proceesing, bukubuku terkait data mining, tutorial penggunaan software Rapidminer dan referensi lainnya.

3. Pengumpulan Data

Data yang dikumpulkan diperoleh melalui wawancara dan pengamatan secara langsung kelapangan yaitu UD. Arif jaya. Data yang dikumpulkan hanya yang berkaitan dengan data keuangan peruhaan atau data keuangan yang terlebih dahulu ditransformasikan,

4. Menganalisis Data

Data yang dikumpulkan akan dianalisis menggunakan teknik data mining dengan metode neive bayes.

5. Penerapan Sistem

Hasil analisis data yang dilakukan secara manual menggunakn metode neive bayes kemudian diintergrasikan software untuk mengatahui apakah hasil yang diperoleh memiliki kesesuaian dan memiliki tingkat akurasi yang baik.

\section{HASIL DAN PEMBAHASAN}

Hasil pengumpulan data akan dilakukan transfromasi data terlebih dahulu yaitu dengan melakukan seleksi data, transformasi data, dan pembersihan data untuk dijadikan sebegai decission system yang akan diterapkan kedalam metode naive bayes.decission system akan menjelaskan sejumlah $n$ objek, E1, E2, E3,...,E120. Dengan atribut kondisi Omset, Pembelian, Stok dan Biaya. Sedangkan yang menjadi atribut kuputusan adalah Keuntungan.

Adapun decission system yang telah diproses tersebut yaitu sebagai berikut : 
DOI: https://doi.org/10.33330/jurteksi.v6i1.393

Available online at http://jurnal.stmikroyal.ac.id/index.php/jurteksi

Tabel 1. Decission System

\begin{tabular}{|c|c|c|c|c|c|}
\hline $\begin{array}{c}\text { Obj } \\
\text { ek }\end{array}$ & $\begin{array}{c}\text { Omse } \\
t\end{array}$ & $\begin{array}{c}\text { Pemb } \\
\text { elian }\end{array}$ & Stok & Biaya & $\begin{array}{c}\text { Keuntu } \\
\text { ngan }\end{array}$ \\
\hline E1 & Target & Besar & $\begin{array}{c}\text { Banya } \\
\text { k }\end{array}$ & Efisien & $\begin{array}{c}\text { Target } \\
\text { Tercapai }\end{array}$ \\
\hline E2 & Target & Besar & $\begin{array}{c}\text { Banya } \\
\text { k }\end{array}$ & Efisien & $\begin{array}{c}\text { Target } \\
\text { Tercapai }\end{array}$ \\
\hline E3 & Target & Besar & $\begin{array}{c}\text { Banya } \\
\text { k }\end{array}$ & Efisien & $\begin{array}{c}\text { Target } \\
\text { Tercapai }\end{array}$ \\
\hline E4 & Target & Besar & $\begin{array}{c}\text { Banya } \\
\text { k }\end{array}$ & Efisien & $\begin{array}{c}\text { Target } \\
\text { Tercapai }\end{array}$ \\
\hline E5 & Target & Besar & $\begin{array}{c}\text { Banya } \\
\text { k }\end{array}$ & Efisien & $\begin{array}{c}\text { Target } \\
\text { Tercapai }\end{array}$ \\
\hline E6 & Target & Besar & $\begin{array}{c}\text { Banya } \\
\text { k }\end{array}$ & Efisien & $\begin{array}{c}\text { Target } \\
\text { Tercapai }\end{array}$ \\
\hline E7 & Target & Besar & $\begin{array}{c}\text { Banya } \\
\text { k }\end{array}$ & Efisien & $\begin{array}{c}\text { Target } \\
\text { Tercapai }\end{array}$ \\
\hline E8 & Target & Besar & $\begin{array}{c}\text { Banya } \\
\text { k }\end{array}$ & Efisien & $\begin{array}{c}\text { Target } \\
\text { Tercapai }\end{array}$ \\
\hline$\ldots$. & $\ldots$. & $\ldots$. & $\ldots$. & $\ldots$ & $\ldots$. \\
\hline $\begin{array}{c}\mathrm{E} 11 \\
9\end{array}$ & Target & Kecil & $\underset{\mathrm{t}}{\text { Sediki }}$ & $\begin{array}{c}\text { Tidak } \\
\text { Efisien }\end{array}$ & $\begin{array}{c}\text { Target } \\
\text { Tercapai }\end{array}$ \\
\hline $\begin{array}{c}\mathrm{E} 12 \\
0\end{array}$ & Target & Kecil & $\underset{\mathrm{t}}{\text { Sediki }}$ & $\begin{array}{c}\text { Tidak } \\
\text { Efisien }\end{array}$ & $\begin{array}{c}\text { Target } \\
\text { Tercapai }\end{array}$ \\
\hline
\end{tabular}

Selanjutnya menghitung probabilitas dari masing-masing atribut mulai dari omset, pembelian, stok dan biaya serta atibut keputusan yaitu keuntungan yang diperoleh. Adapun tabel probabilitas tersebut sebagai berikut.

\section{Tabel 2. Nilai Probabilitas Omset}

\begin{tabular}{ccccc}
\hline \multirow{2}{*}{ Omset } & \multicolumn{2}{c}{ Jumlah Kejadian } & \multicolumn{2}{c}{ Probabilitas } \\
\cline { 2 - 5 } & $\begin{array}{c}\text { "Keuntungan" } \\
\text { Tercapai }\end{array}$ & $\begin{array}{c}\text { Tidak } \\
\text { Tercapai }\end{array}$ & Tercapai & $\begin{array}{c}\text { Tidak } \\
\text { Tercapai }\end{array}$ \\
\hline Terget & 36 & 10 & 0,480 & 0,222 \\
Lebih & 31 & 0 & 0,413 & 0,000 \\
Kurang & 8 & 35 & 0,107 & 0,778 \\
Jumlah & 75 & 45 & 0,625 & 0,375 \\
\hline
\end{tabular}

Tabel 3. Nilai Probabilitas Pembelian

\begin{tabular}{|c|c|c|c|c|}
\hline \multirow{2}{*}{$\begin{array}{l}\text { Pembel } \\
\text { ian }\end{array}$} & \multicolumn{2}{|c|}{$\begin{array}{l}\text { Jumlah Kejadian } \\
\text { "Keuntungan" }\end{array}$} & \multicolumn{2}{|c|}{ Probabilitas } \\
\hline & $\begin{array}{c}\text { Tercap } \\
\text { ai } \\
\end{array}$ & $\begin{array}{l}\text { Tidak } \\
\text { Tercapai }\end{array}$ & $\begin{array}{c}\text { Terca } \\
\text { pai }\end{array}$ & $\begin{array}{l}\text { Tidak } \\
\text { Tercapai }\end{array}$ \\
\hline Besar & 50 & 22 & 0,667 & 0,489 \\
\hline Kecil & 25 & 23 & 0,333 & 0,511 \\
\hline Jumlah & 75 & 45 & 0,625 & 0,375 \\
\hline
\end{tabular}

Tabel 4. Nilai Probabilitas Stok

\begin{tabular}{ccccc}
\hline \multirow{2}{*}{ Stok } & \multicolumn{2}{c}{$\begin{array}{c}\text { Jumlah Kejadian } \\
\text { "Keuntungan" }\end{array}$} & \multicolumn{2}{c}{ Probabilitas } \\
\cline { 2 - 5 } & $\begin{array}{c}\text { Terca } \\
\text { pai }\end{array}$ & $\begin{array}{c}\text { Tidak } \\
\text { Tercapai }\end{array}$ & $\begin{array}{c}\text { Terca } \\
\text { pai }\end{array}$ & $\begin{array}{c}\text { Tidak } \\
\text { Tercapai }\end{array}$ \\
\hline Banyak & 58 & 22 & 0,773 & 0,489 \\
Sedikit & 17 & 23 & 0,227 & 0,511 \\
Jumlah & 75 & 45 & 0,625 & 0,375 \\
\hline
\end{tabular}

Tabel 5. Nilai Probabilitas Biaya

\begin{tabular}{ccccc}
\hline \multirow{2}{*}{ Biaya } & \multicolumn{2}{c}{ Jumlah Kejadian } & \multicolumn{2}{c}{ Probabilitas } \\
\cline { 2 - 5 } & $\begin{array}{c}\text { Terca } \\
\text { pai }\end{array}$ & $\begin{array}{c}\text { Tidak } \\
\text { Tercapai }\end{array}$ & $\begin{array}{c}\text { Terca } \\
\text { pai }\end{array}$ & $\begin{array}{c}\text { Tidak } \\
\text { Tercapai }\end{array}$ \\
\hline $\begin{array}{c}\text { Efesien } \\
\text { Tidak }\end{array}$ & 58 & 0 & 0,773 & 0 \\
Efesien & 17 & 45 & 0,227 & 1 \\
Jumlah & 75 & 45 & 0,625 & 0,375 \\
\hline
\end{tabular}

Tabel 6. Nilai Probabilitas Keuntungan

\begin{tabular}{ccccc}
\hline \multirow{2}{*}{$\begin{array}{c}\text { Dipilih } \\
\text { Untuk } \\
\text { Keuntungan }\end{array}$} & \multicolumn{2}{c}{$\begin{array}{c}\text { Jumlah Kejadian } \\
\text { "Keuntungan" }\end{array}$} & \multicolumn{2}{c}{ Probabilitas } \\
\cline { 2 - 5 } & Tercapai & $\begin{array}{c}\text { Tidak } \\
\text { Tercapai }\end{array}$ & Tercapai & $\begin{array}{c}\text { Tidak } \\
\text { Tercapai }\end{array}$ \\
\hline Jumlah & 75 & 45 & 0,625 & 0,375 \\
\hline
\end{tabular}

Setelah mendapatkan nilai probabilitas diatas, maka akan dilakukan uji test berikut :

1. Apabila diketahui hasil keuntungan dengan omsetnya kurang, pembelian nya kecil, stok nya banyak, biaya nya tidak efesien. Maka dapat dihitung :

Tercapai $=0,107 * 0,333 * 0,733 * 0,227$ $* 0,625=0,004$

Tidak Tercapai $=$ $0,778 * 0,511 * 0,489 * 1 * 0,375=0,073$

Nilai probabilitas diatas dapat dihitung melakukan normalisasi terhadap likelihood tersebut sehingga jumlah nilai yang diperoleh $=1$

Probabilitas Tercapai

$$
=\frac{0,004}{0,004+0,073}=0,052
$$


DOI: https://doi.org/10.33330/jurteksi.v6i1.393

Available online at http://jurnal.stmikroyal.ac.id/index.php/jurteksi

Probabilitas Tidak Tercapai

$$
=\frac{0,073}{0,073+0,004}=0,948
$$

2. Apabila diketahui hasil keuntungan dengan omsetnya target, pembelian nya besar, biaya nya tidak efesien. Maka dapat dihitung :

Tercapai

$0,480 * 0,667 * 0,227 * 0,625$

$$
=0,246
$$

Tidak

$$
\text { Tercapai }=0,222 * 0,489 * 1 * 0,375
$$

$$
=0,041
$$

Nilai probabilitas diatas dapat dihitung melakukan normalisasi terhadap likelihood tersebut sehingga jumlah nilai yang diperoleh $=1$

Probabilitas Tercapai

$$
=\frac{0,246}{0,246+0,041}=0,857
$$

Probabilitas Tidak Tercapai

$$
=\frac{0,041}{0,041+0,246}=0,143
$$

3. Apabila diketahui hasil keuntungan dengan omsetnya kurang, pembelian nya kecil, biaya nya tidak efesien. Maka dapat dihitung :

Tercapai

$$
\begin{gathered}
0,107 * 0,333 * 0,227 * 0,625 \\
=0,005
\end{gathered}
$$

Tidak

Tercapai $=0,778 * 0,511 * 1 * 0,375$

$$
=0,149
$$

Nilai probabilitas diatas dapat dihitung melakukan normalisasi terhadap likelihood tersebut sehingga jumlah nilai yang diperoleh $=1$

Probabilitas Tercapai

$$
=\frac{0,005}{0,005+0,149}=0,032
$$

Probabilitas Tidak Tercapai

$$
=\frac{0,149}{0,149+0,005}=0,968
$$

Selanjutnya proses pengujian menggunakan alat bantu software rapidminer. Langkah awal melakukan proses import data berupadecission system. Adapun data import yang dimaksud yaitu sebagai berikut :

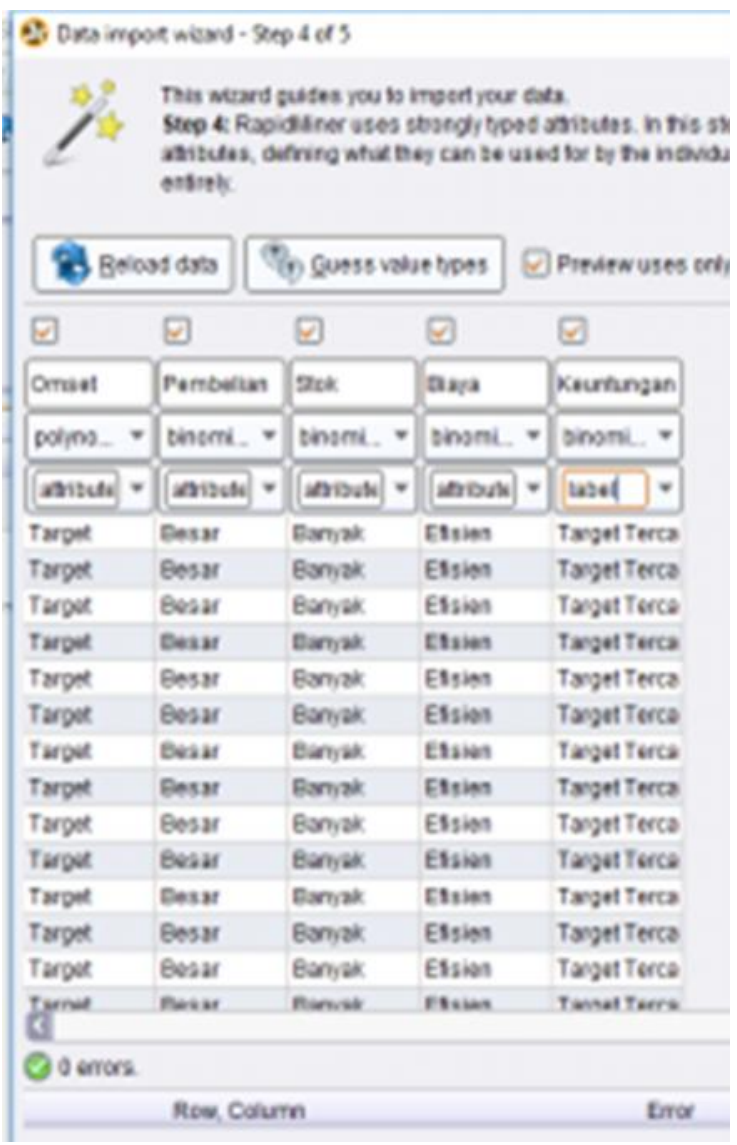

Gambar 2. Data Import Wizard

Setelah itudilakukan proses koneksi antara data yang telah diimport dengan operator metode naive bayes didalam menu operator. Kemudian men-drag data dan operator tersebut atau melakukan proses pemindahan kedalam jendela process. Maka terlihat koneksi tersebut pada gambar sebagai berikut. 
DOI: https://doi.org/10.33330/jurteksi.v6i1.393

Available online at http://jurnal.stmikroyal.ac.id/index.php/jurteksi

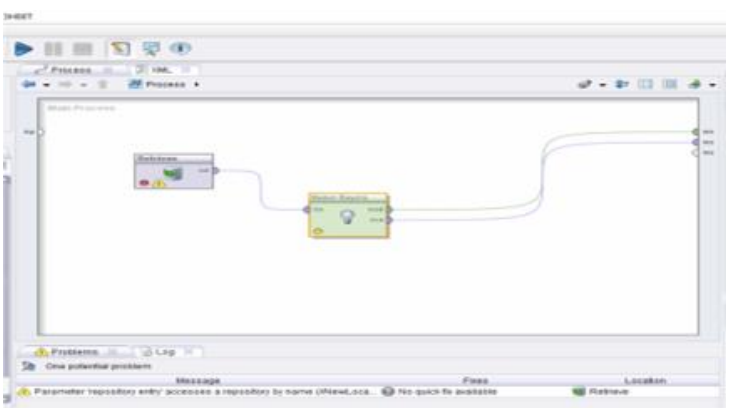

Gambar 3. Koneksi Data Import dengan Metode Naive Bayes

Selanjutnya dilakukan proses menjalankan aplikasi dengan mengklik tombol run pada jendela aplikasi. Sehingga dari hasil proses yang dijalankan mendapatkan hasil yaitu sebuah probabilitas kemunculan setiap nilai dari masing-masing atribut kondisi hasil keuntungan. Hasil probabilitas yang telah diproses dapat terlihat pada gambar berikut ini.

\begin{tabular}{|c|c|c|c|}
\hline \multicolumn{4}{|c|}{ Eile Edit Process Iools View Help } \\
\hline$[0$ & a & 12 & $\mathbb{1}$ \\
\hline \multicolumn{4}{|c|}{ 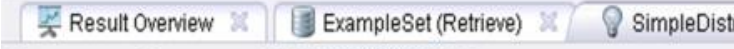 } \\
\hline \multicolumn{4}{|c|}{ Text View $\bigcirc$ Plot View $\bigcirc$ Distribution Table: $\bigcirc$ Annotations } \\
\hline Attribute & Parameter & Target Tercapai & Target Tdk Tercapai \\
\hline Omset & value $=$ Target & 0.480 & 0.222 \\
\hline Omset & value $=$ Lebih & 0.413 & 0.000 \\
\hline Omset & value=Kurang & 0.107 & 0.777 \\
\hline Omset & value $=$ unknown & 0.000 & 0.000 \\
\hline Pembelian & value $=$ Besar & 0.667 & 0.489 \\
\hline Pembelian & value $=$ Kecil & 0.333 & 0.511 \\
\hline Pembelian & value $=$ unknown & 0.000 & 0.000 \\
\hline Stok & value $=$ Banyak & 0.773 & 0.489 \\
\hline Stok & value $=$ Sedikit & 0.227 & 0.511 \\
\hline Stok & value $=$ unknown & 0.000 & 0.000 \\
\hline Biaya & value=Efisien & 0.773 & 0.000 \\
\hline Biaya & value $=$ Tidak Efisien & 0.227 & 1.000 \\
\hline Biaya & value $=$ unknown & 0.000 & 0.000 \\
\hline
\end{tabular}

Gambar 4. Nilai Probabilitas

Gambar tersebut merupakan probabilitas kemunculan dari masing- masing atribut yang dihasiilkan software rapidminer. maka selanjutnya akan dilakukan proses test set berikut.

1. Apabila diketahui hasil keuntungan dengan omset target, pembelian nya kecil, stok nya sedikit, biaya nya tidak efesien. Maka dapat dihitung : Tercapai

$$
\begin{gathered}
0,480 * 0,333 * 0,227 * 0,227 * 0,625 \\
=0,005
\end{gathered}
$$

Tidak Tercapai = $0,222 * 0,511 * 0,511 * 1 * 0,291=0,017$

Maka proses selanjutnya menghitung :

Probabilitas Tercapai

$$
\begin{aligned}
& =\frac{0,005}{0,005+0,017}=0,227 \\
& \text { Probabilitas Tidak Tercapai } \\
& =\frac{0,017}{0,017+0,005}=0,773
\end{aligned}
$$

2. Apabila diketahui hasil keuntungan dengan omset nya kurang, pembelian nya besar, dan biaya nya tidak efesien. Maka dapat dihitung :

Tercapai $=0,107 * 0,667 * 0,227 * 0,625$

$$
=0,010
$$

Tidak

Tercapai

$=0,777 * 0,489 * 1 * 0,291=0,111$

Maka proses selanjutnya menghitung

Probabilitas Tercapai

$=\frac{0,010}{0,010+0,111}=0,083$

Probabilitas Tidak Tercapai

$=\frac{0,111}{0,111+0,010}=0,917$

3. Apabila diketahui hasil keuntungan dengan omsetnya target, pembelian nya kecil. Maka dapat dihitung : Tercapai $=0,480 * 0,333 * 0,625=$ 0,100

Tidak Tercapai $=0,222 * 0,511 * 0,291$

$$
=0,033
$$


DOI: https://doi.org/10.33330/jurteksi.v6i1.393

Available online at http://jurnal.stmikroyal.ac.id/index.php/jurteksi

Maka proses selanjutnya menghitung

Probabilitas Tercapai

$=\frac{0,100}{0,100+0,033}=0,752$

Probabilitas Tidak Tercapai

$=\frac{0,033}{0,033+0,100}=0,248$

\section{SIMPULAN}

Dari hasil integrasi metode naive bayes dan software rapidmineryang telah dilakukanadalah metode naive bayes menghasilkan prediksi yang akan membantu pelaku usaha dalam meningkatkan hasil keuntungkan, begitu pun dengan software rapidminer yang dapat membantu mempermudahkan proses prediksi hasil keuntungan.

\section{UCAPAN TERIMA KASIH}

Ucapan terima kasih kepada DRPM Direktorat Jenderal Penguat Riset dan Pengembangan Kementrian Riset, Teknologi dan Pendidikan Tinggi Sesuai dengan Kontrak Penelitian PDP Tahun Anggaran 2019.

\section{DAFTAR PUSTAKA}

[1] Ridwan, M., Suyono, H., \& Sarosa, M. (2013). Penerapan Data Mining Untuk Evaluasi Kinerja Akademik Mahasiswa Menggunakan Algoritma Naive Bayes Classifier. jurnal EECCIS, 7(1), 59-64.

[2] Adiwiratama, J. (2012). Pengaruh Informasi Laba, Arus Kas dan Size Perusahaan terhadap return Saham (Studi empiris pada perusahaan manufaktur yang terdaftar di BEI). JINAH (Jurnal Ilmiah Akuntansi dan Humanika), 2(1).

[3] Hartono, S. (2012). Pengaruh Informasi Laba Dan Arus Kas Terhadap Harga Saham. Akurat: Jurnal Ilmiah Akuntansi, 3(7).

[4] Pane, D. K. (2013). Implementasi Data Mining Pada Penjualan Produk Elektronik Dengan Algoritma Apriori (Studi Kasus: Kreditplus). Pelita Informatika: Informasi dan Informatika, 4(3).

[5] Mabrur, A. G. (2012). Penerapan data mining untuk memprediksi kriteria nasabah kredit. KOMPUTA: Jurnal Komputer dan Informatika, 1(1).

[6] Saleh, A. (2015). Implementasi metode klasifikasi naive bayes dalam memprediksi besarnya penggunaan listrik rumah tangga. Creative Information Technology Journal, 2(3), 207-217.

[7] Zulkifli, A. (2016). Metode C45 Untuk Mengklarifikasi Pelanggan Perusahaan Telekomunikasi Seluler. Riau Journal Of Computer Science, 2(1), 65-76. 